\title{
In Vitro Alpha Glucosidase Activity of Uncaria gambir Roxb. and Syzygium polyanthum (Wight) Walp. from West Sumatra, Indonesia
}

\author{
Silvy Arundita ${ }^{1}$, Febry Kurniawan ${ }^{1}$, Friardi Ismed ${ }^{2}$, Rauza Sukma Rita ${ }^{1}$, Deddi Prima Putra ${ }^{2 \star}$ \\ ${ }^{1}$ Faculty of Medicine, Andalas University, Padang, West Sumatera, Indonesia; ${ }^{2}$ Faculty of Pharmacy, Andalas University, Limau \\ Manis, Padang, West Sumatera, Indonesia
}

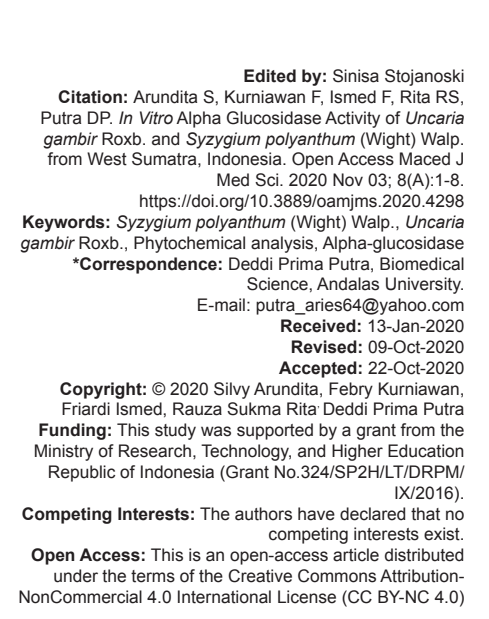

Introduction

Large numbers of medicinal herbs were identified in Indonesia. These herbs, leaves, stems, or roots are used as a source of medicinal products. The benefit of these medicinal herbs is not only related to the secondary metabolites produced by these plants as a defense mechanism against injury and infection but also play a vital role in the medicinal field, because of its healing capacity. The content of secondary metabolites active in herbs can vary among others due to plant species, the country of origin, its growth phase, and seasonal changes. These secondary metabolites include among others: Phenolic, flavonoids, and their derivatives (tannins, proanthocyanidins, and vitamins) [1].

Phenolic contents are known to be the most important class of phytochemicals in the plant. They can be classified into two main groups, polyphenols and flavonoids. Phenolics are usually associated with the inhibition of oxidative stress-related diseases such as diabetes and cancer in humans. Flavonoids are polyphenolic contents, commonly found in plants. Besides being a potential antioxidant compound, flavonoid also exhibits potential pharmacological activities [2].
Proanthocyanidins or condensed tannins are flavonoid oligomers that are widely distributed in plants. They have beneficial effects on human health. Flavan-3-ols such as catechin are a component of proanthocyanidins and serve as flavor and astringency in tea also exhibit potential pharmacological activities such as anticarcinogenic.

Drying is basically defined as a process of water removed and decreasing of herbs moisture content, aimed at preventing microbial and enzymatic activity, consequently preserving the product for extend shelf life. Understanding at what level different drying techniques may influence the content of compounds with a proven effect on human organism may lead to postharvest management of these compounds profile in the future. There are some published data reports on various drying processes of $U$. gambir (Uncaria gambir Roxb ) leaf which have an impact on compound variations and their bioactivity [3], [4]. Thus, the search for potential keeping the phytochemical in these herbs has gained increasing interest among researchers. In literature, there is only a small amount of information about the changes of phenolic compounds and antioxidant potential in herbs in the context of drying together with the variability of their composition and biological activity. 
Diabetes is a common disease in developing countries and developed countries. DM (diabetes mellitus) is a metabolic disorder with multiple etiologies characterized by chronic hyperglycemia with disturbances of carbohydrate, fat, and protein metabolism resulting from defects in insulin secretion, insulin action, or both. The global prevalence was estimated approximately 382 million people in 2013 suffer from DM and it is projected that it will increase to 592 million in 2035 if no action is taken [5].

Some management strategy diabetes is by giving insulin, correct disorders of insulin in the pancreas (sulfonylureas, glinides, incretin mimetic, and inhibitors of DPP4 [dipeptidyl peptidase-4]), repair impaired insulin on the insulin receptor (Biguanides and Thiazolidinediones), and slowing digestion and absorption of carbohydrates in the intestines to maintain the level post-prandial glucose (inhibitor of alpha-glucosidase and alpha-amylase). Alpha-glucosidase is an enzyme found in the brush border of the small intestine (intraluminal). This enzyme works by breaking the disaccharide into monosaccharides. Monosaccharides will be absorbed into the blood vessels, then blood glucose levels rise. Acarbose is inhibitors of the intestinal brush border alpha-glucosidases. It is an oligosaccharide analog that binds more avidly than natural carbohydrate to the intestinal disaccharides such as alphaglucosidase. Hence, the absorption of most carbohydrates is delayed. This competitive inhibition of alpha-glucosidase limits the post-prandial rise of glucose. Unfortunately, current antidiabetic therapies are based on synthetic drugs that very often have side effects such as hypoglycemia, weight gain, gastrointestinal disturbances, nausea, diarrhea, liver, and heart failure [6]. Therefore, antidiabetic agents which can provide a minimal effect on the side effects are a challenge in this century. Some herbs used by a traditional society as the lowering of blood sugar agent is thought to have minimal side effects.

Fresh herbs $\left(U\right.$. gambir and S. polyanthum $\left.{ }^{1}\right)$ are an excellent source of phenolic compounds which have been reported to show good alphaglucosidase inhibitory activity [7], [8]. Therefore, our present study reveals the qualitative measurement of potential natural constituents and quantification total phenolics, flavonoids, proanthocyanidins, and alpha-glucosidase inhibition activity of different parts U. gambir and S. polyanthum in Padang, West Sumatra area [9], [10], [11]. Furthermore, in this work, we evaluated the results of three drying methods of $U$. gambir leaves and its derived fractions and compound in relation to active groups (phenolics, flavonoids, and proanthocyanidins) and biological activity (alpha-glucosidase inhibitory activity) [12].

1 S. polyanthum : Syzygium polyanthum (Wight) Walp

\section{Materials and Methods}

\section{Identification and plant material}

Five kilograms fresh and healthy leaves, stems, and roots of $U$. gambir and $S$. polyanthum were collected from KTOF (Kebun Tumbuhan Obat Farmasi), Sumatran Biota Laboratory, Andalas University. The sample specimen was identified based on the taxonomical characteristics and deposited in the herbarium of Andalas University. The leaf, stem, and root were washed thoroughly in distilled water and the surface water was removed by air under shade. All of the samples were dried according to the method described by Roshanak, Sudibyo and Joseph, and Chua et al. with a slight modification, on a naturally dried by air under shade $\left(20^{\circ} \mathrm{C}, 3\right.$ days), except for gambir leaves [13], [14], [15]. The leaves were dried using one of the following drying methods; oven $\left(50^{\circ} \mathrm{C}, 24 \mathrm{~h}\right)$, steam blanching $\left(100^{\circ} \mathrm{C}, 10\right.$ $\mathrm{min}$ ) by a household steam cooker followed by naturally dried by air under shade $\left(25^{\circ} \mathrm{C}, 3\right.$ days), and naturally dried by air under shade $\left(25^{\circ} \mathrm{C}, 3\right.$ days). After that, all of the samples were milled into powder by a grinder. The resulting powders were immediately packaged and kept in the dark place before extraction and analyses.

\section{Chemicals}

alpha-glucosidase from Saccharomyces cerevisiae (EC 3.2.1.20), substrate $\rho$-nitrophenyl- $\alpha$-Dglucopyranoside (pNPG) were purchased from Sigma Aldrich, Singapore. (+)-Catechin was from U. gambirRoxb. The purity of the isolated (+)-catechin was approximately $99.9 \%$ and was purchased from PT. Andalas Sitawa Fitolab. All other chemicals were analytical grade and purchased from Sigma Aldrich, Singapore.

\section{Preparation of methanol extract and} proanthocyanidin fraction

The powdered leaves, stems, and root of $U$. gambir and S. polyanthum were macerated in methanol $70 \%$. Maceration took 9 days at room temperature and done by changing the solvent in every 3 days. The methanol extract was subsequently filtered through Whatman No. 1 filter paper and transferred into the sample holder of the rotary flash evaporator for the evaporation of the solvent to obtained extraction yields of $U$. gambir's naturally dried leaf $(24,99 \%), U$. gambir's oven-dried leaf $(18,65 \%), U$. gambir's steam dried leaf $(46.11 \%)$, U. gambir's stems $(8,95 \%)$, U. gambir's roots $(15,28 \%), S$. polyanthum's leaf $(19,39 \%)$, S. polyanthum's stems $(22,78 \%)$, and S. polyanthum's roots $(7,63 \%)$.

Five hundred grams of methanol crude extracts of U. gambir's oven dried leaf, U. gambir's stem dried leaf, $S$. polyanthum's leaf, and S. polyanthum's stems were then fractionated successively with hexane, ethyl acetate, and 
butanol to obtained fractionated yields of hexane fraction of $U$. gambir's oven dried leaf $(0 \%)$, ethyl acetate fraction of $U$. gambir's oven dried leaf $(40,6 \%)$, butanol fraction of $U$. gambir's oven dried leaf $(10 \%)$, hexane fraction of $U$. gambir's stems $(5,10 \%)$, ethyl acetate fraction of $U$. gambir's stems $(20,4 \%)$, butanol fraction of $U$. gambir's stems $(3,06 \%)$, hexane fraction of $S$. polyanthum's leaf $(0 \%)$, ethyl acetate fraction of S. polyanthum's leaf $(50 \%)$, butanol fraction of S. polyanthum's leaf (13\%), S. hexane fraction of polyanthum's stems $(3,10 \%)$, ethyl acetate fraction of S. polyanthum's stems $(24,76 \%)$, and butanol fraction of $S$. polyanthum's stems $(9,30 \%)$. Ten grams of obtained butanol fraction of $U$. gambir's oven-dried leaf were directly subjected to a Diaion HP-20 (Sigma Aldrich, Singapore) column $\left(9 \mathrm{~cm}\right.$ i.d. $\times 60 \mathrm{~cm}$ ) with $\mathrm{H}_{2} \mathrm{O}$ containing increasing amounts of $\mathrm{MeOH}$ in stepwise gradient mode and then fractioned into 10 subfractions SA01-SA10, respectively. Of the obtained subfractions, SA03 was a proanthocyanidin fraction, a brown powder $31,2 \mathrm{mg}(0.32 \%)$. All of the extracts were preserved in a brown bottle until further use.

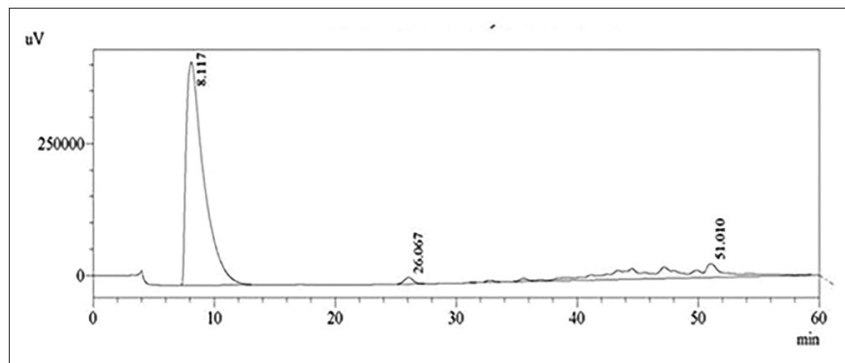

Figure 1: The purity of proanthocyanidin fraction was determined using HPLC analysis. The amount was measured by HPLC technique. The peak proanthocyanidin fraction was observed at a retention time of $8,117 \mathrm{~min}$

\section{HPLC (High-performance Liquid Chromatography) analysis}

The HPLC system (Shimadzu, Japan) consisted of a binary gradient pump (LC- 10AD). The quantification of proanthocyanidin fraction was set at $254 \mathrm{~nm}$. The chromatographic separation was performed at ambient temperature (25-28 C) using Hypersil BSD C18 column $(4,6 \times 100 \mathrm{~mm}, 3 \mu \mathrm{m}$ size) (Thermo Scientific, USA) with a C18 guard column. The mobile phase consisted of water $(A)$ and methanol $(B)$ were delivered at flow rate of $1000 \mathrm{ml} / \mathrm{min}$ following programmed gradient elution: $100 \%(A)$ isocratic for $5 \mathrm{~min}, 90 \%(A)$ for $5 \mathrm{~min}, 80 \%(A)$ for $5 \mathrm{~min}, 70 \%$ (A) for $5 \mathrm{~min}, 60 \%$ (A) for $5 \mathrm{~min}, 50 \%(A)$ for $5 \mathrm{~min}, 40 \%$ (A) for $5 \mathrm{~min}, 30 \%$ (A) for $5 \mathrm{~min}, 15 \%(A)$ for $5 \mathrm{~min}, 5 \%(\mathrm{~A})$ for $5 \mathrm{~min}$, and $0 \%(\mathrm{~A})$ isocratic for $10 \mathrm{~min}$ post-run for reconditioning. Sample volume injection was adjusted to $10 \mu \mathrm{L}$. Total running time was $60 \mathrm{~min}$. All solution of the mobile phase were freshly prepared, filtered through $0.45 \mu \mathrm{m}$ Nylon filter under vacuum and degassed by sonication for $20 \mathrm{~min}$ before use. The result was analyzed using ChemStation software. The percentage of proanthocyanidin fraction was $\geq 75 \%$ calculated based on the peak area (Figure 1).

\section{Qualitative phytochemical analysis}

The viscous extracts (50 mg) were diluted using methanol. Identification of the presence of phenolic, alkaloid, saponin, steroid, terpenoid, and flavonoid conducted in accordance with procedures of Harborne [16].

\section{Evaluation of bioactive constituents}

\section{Total phenolic content}

A Folin-Ciocalteu method based on Slinkard and Singleton report was applied to determine the total amount of phenolic compounds in methanol extract from different parts of $U$. gambir and S. polyanthum [17]. The reduction of Folin-Ciocalteu reagent by phenolic ion will change its solution color into blue. The reduction of complex will increase when the extract contains more phenolic compounds. Thus, the color will be darker and the absorbance will be higher. Samples $50 \mu$ of each plant part was added to $50 \mu$ l aquadest, $50 \mu$ of $7,5 \%$ Folin-Ciocalteu in aquadest, incubated at $37^{\circ} \mathrm{C}$ for 8 min. Finally, $50 \mu \mathrm{l}$ of $1 \%$ sodium hydroxide was added and incubated at $37^{\circ} \mathrm{C}$ for $60 \mathrm{~min}$. Absorbance values of the solutions were measured at $750 \mathrm{~nm}$. Total phenolic contents were determined as a gallic acid equivalent (GAE) based on Folin-Ciocalteu calibration curve using gallic acid as the standard and expressed as mg gallic acid per $100 \mathrm{~g}$ of dry mass (\% b/b).

\section{Flavonoid content}

The total soluble flavonoid contents of methanol extract of different parts of U. gambir and S. polyanthum were estimated by the spectrophotometric method [18]. The aluminum chloride forms acid-stable complexes with the hydroxyl group of the flavonoids and flavonols. $0.5 \mathrm{ml}$ of stock solution of the extract, $1.5 \mathrm{ml}$ methanol, $0.1 \mathrm{ml}$ of $10 \%$ aluminum chloride, and $0.1 \mathrm{ml}$ of $1 \mathrm{M}$ sodium acetate was added to reaction tubes and volume was made up to $5 \mathrm{ml}$ with distilled water. After incubation at room temperature for $30 \mathrm{~min}$, the absorbance of the reaction mixture was measured at $415 \mathrm{~nm}$. Total flavonoid content was calculated by extrapolating the absorbance of the reaction mixture on a standard curve of rutin. The total flavonoid content was expressed as equivalent to rutin in $\% \mathrm{~b} / \mathrm{b}$ of the extracts.

\section{Proanthocyanidin content}

Proanthocyanidins in the sample solutions of methanol extract from different parts of $U$. gambir and S. polyanthum were determined by the vanillin- $\mathrm{HCl}$ assay described by Sun et al. [19]. The vanillin reaction involves the reaction of an aromatic aldehyde, vanillin, with the meta substituted ring of flavanols to yield a red adduct [20]. To $100 \mu \mathrm{l}$ of test solution or methanol (control) in a test tube, $2.5 \mathrm{ml}$ of $8 \%$ hydrogen chloride 
in glacial acetic acid and $2.4 \mathrm{ml}$ of $1 \%$ vanillin in glacial acetic acid solution was added. The reaction mixture was incubated for $5 \mathrm{~min}$ at room temperature and the absorbance at $510 \mathrm{~nm}$ was measured. The data for proanthocyanidin contents were expressed as $\mathrm{mg}$ of $(+)$-catechin equivalent weight (CAE)/ $100 \mathrm{~g}$ of dry mass (\% b/b).

\section{alpha-glucosidase inhibitory activity}

The alpha-glucosidase inhibitory activity of methanol extract from different parts of $U$. gambir and S. polyanthum was determined according to the method described by Mohamed et al. with a slight modification [21]. A mixture of $50 \mu \mathrm{l}$ of the sample solution and $100 \mu \mathrm{l}$ of $0.1 \mathrm{M}$ phosphate buffer containing alpha-glucosidase solution $(1 \mathrm{U} / \mathrm{ml})$ was incubated in 96 well plates at $25^{\circ} \mathrm{C}$ for $10 \mathrm{~min}$. After preincubation, $50 \mu \mathrm{l}$ of $5 \mathrm{mM}$ pNPG solution in $0.1 \mathrm{M}$ phosphate buffer was added to each well at timed intervals. The reaction mixtures were incubated at $25^{\circ} \mathrm{C}$ for $5 \mathrm{~min}$. Absorbance was recorded at $405 \mathrm{~nm}$ by a microplate reader (Bio-Rad). Acarbose was used as a positive control. The alpha-glucosidase inhibitory activity was expressed as inhibition percent and was calculated as follows:

Inhibition $(\%)=\left(A_{\text {ref }}-A_{\text {sam }}\right) / A_{\text {ref }} \times 100$; where $A_{\text {ref }}$ is the absorbance of the reference; $A_{\text {sam }}$ is the absorbance of the test samples.

\section{Statistical analysis}

All data were conducted in triplicate. The reported value for each sample was calculated as the mean \pm SE of three measurements.

\section{Results and Discussion}

\section{Extraction yields and phytochemical analysis}

Percentage yield (\% w/w) was determined by comparing the weight of the dried leaves with the weight of the crude extract produced. The highest extraction yield of methanol extract was found on U. gambir's steam bleaching leaf extracts $(46,11 \%)$ followed by $U$. gambir's naturally (24.99\%) and oven-dried leaf extracts (18,65\%). Thermal treatment is considered as an efficient method to inactivate enzymes. Conventionally, steam blanching is normally applied for enzyme inactivation [22]. Our result proved that steam bleaching resulted in increases in the yields. One possible explanation is that a short blanching could be beneficial for the texture of the leaf for the extraction process.

S. polyanthum's stem extracts and U. gambir's leaf extracts showed higher yields than other extracts compared on the same species. These differences could be attributed to the high levels of the total component in $S$. polyanthum's stem extracts and $U$. gambir's leaf extracts. Moreover, S. polyanthum's stem extracts and U. gambir's leaf extracts are seemed to be rather narrow compared with other parts, morphologically, thus facilitates its extraction. These reasons also apply to $U$. gambir's leaf extracts.

Phytochemical screening is the major tool to bring about the wonderful potential of plants. Plant metabolites were responsible for potential activities. Phytochemical screening in this study was aimed at detecting the presence of phenolic, alkaloid, saponins, steroid, terpenoid, and flavonoid. General reactions revealed the presence or absence of these compounds in the tested extracts. The resulting qualitative analysis showed that all parts of $U$. gambir contained phenolic, alkaloids, and flavonoids. Similar observations have been made by Thorpe and Whiteley and Amir et al., while saponin, steroid, and terpenoid were not detected in the overall part of $U$. gambir (Table 1) [23], [24]. Saponin and steroid only found on $U$. gambir's oven-dried and steam bleaching leaves, yet terpenoid found on all of $U$. gambir part extracts, except leaves dried steam process. Among the extracts, U. gambir's oven-dried leaf provided a strong positive for the natural constituents such as phenolic, alkaloid, saponin, steroid, terpenoid, and flavonoid.

All parts of S. polyanthum contained phenolic and flavonoid, while terpenoid and steroid were not detected in overall parts of S. polyanthum. Saponin only detected on leaves and stem of $S$. polyanthum and not found on the root. This result is contrary to the previous literature. Kusuma et al. found that S. polyanthum's leaf grown in Samarinda and Balikpapan, Indonesia did not contain saponin, but flavonoid, alkaloid, tannin, glycoside, terpene, and steroid. S. polyanthum' leaf grown in Medan, Indonesia, contained flavonoid, alkaloid, tannin, and glycoside [25], [26].

\section{Total phenolic, flavonoid, and proanthocyanidin contents}

There are more than 8000 phenolic compounds, which are distributed into classes based on the number of phenolic rings in the structure and the constituents that bind to the rings. Phenolic compounds are further categorized as flavonoids and non-flavonoids. The subgroups within the flavonoid category include flavonols,

Table 1: Phytochemical screening contents

\begin{tabular}{|c|c|c|c|c|c|c|}
\hline Samples & Phenolic & Alkaloid & Saponin & Steroid & Terpenoid & Flavonoid \\
\hline $\begin{array}{l}\text { U. gambir's naturally } \\
\text { dried leaf }\end{array}$ & + & + & - & - & + & + \\
\hline $\begin{array}{l}\text { U. gambir's oven- } \\
\text { dried leaf }\end{array}$ & + & + & + & + & + & + \\
\hline $\begin{array}{l}\text { U. gambir's steam } \\
\text { dried leaf }\end{array}$ & + & + & + & + & - & + \\
\hline U. gambir's stems & + & + & - & - & + & + \\
\hline U. gambir's root & + & + & - & - & + & + \\
\hline S. polyanthum's leaf & + & - & + & - & + & + \\
\hline S. polyanthum's stem & + & - & + & - & + & + \\
\hline S. polyanthum's root & + & - & - & - & + & + \\
\hline
\end{tabular}


flavones, isoflavones, flavanones, anthocyanidins, and flavanols. The flavanols subclass includes catechins and proanthocyanidins [27]. The total phenolic, flavonoid, and proanthocyanidin contents of 8 methanolic extracts from 2 Indonesian medicinal plant species were systematically assessed. Phenolic compounds were found to be the major components of all extracts.

The methods of drying affected the level of phenolics, flavonoids, and proanthocyanidinscompounds in analyzed herbs. U. gambir's steam blanching leaf extract $(42,536 \pm 1,047 \%$ GAE) provided the highest total phenolic content among other parts, followed by $U$. gambir's naturally dried leaf and $U$. gambir's stems extracts which were 29,659 $\pm 2,521 \%$ GAE and 27,735 \pm $1,455 \%$ GAE, respectively. Among three different drying processes, oven-dried process had the lowest phenolic compounds $(17,580 \pm 0,529 \% G A E)$. Proanthocyanidin and flavonoid compounds had a different pattern with phenolic compounds. Proanthocyanidin content of $U$. gambir's steam blanching $(37,927 \pm 1,267 \% \mathrm{CAE})$, naturally $(14,293 \pm 0,671 \% \mathrm{CAE})$, oven-dried leaf $(8,422$ $\pm 0,466 \% \mathrm{CAE}$ ) and flavonoid content of naturally dried leaf $(32,472 \pm 1,095 \%$ RAE), and steam blanching leaf $(29,396 \pm 1,742 \%$ CAE $)$.

The effect of steam blanching process as a pretreatment step on extraction method was tested in this attempt. Similar effects of steaming were reported from Gliszczynska-Swiglo et al. where found a $52 \%$ increase in the total phenolic content in steamed (10 min) broccoli, explaining this by enhanced extractability due to disruption of the polyphenoloxidase, polyphenolprotein complexes [28]. Moreover, steam blanching process has a positive effect on the extractability of flavonoids since in respective samples, flavonoid yields are higher compared to other samples.

In the case of $U$. gambir's oven-dried leaf, where the lowest content of phenolics, flavonoids, and proanthocyanidins compounds existed, it has been already published that some phenolic compounds in plants may be a part of bigger molecules which do not react with Folin-Ciocalteu reagent [29]. It can be suggested that on oven process, these binds with bigger molecules may be existed and it caused the lowest concentration of phenolic compounds. Other, possibility is the bioactive compounds of $U$. gambir's leaf may be destroyed on oven processed at a high temperature.

According to Rahmawati and Fernando and Jaya et al., U. gambir's leaf grown in Kampar, Riau, Indonesia which was dried at $60^{\circ} \mathrm{C}$ oven had phenolic contents of $15.7 \%$ GAE, on the other hand, $43,13 \%$ GAE was in phenolic water extracts of gambir product [29], [30], [31]. The amount of catechin, a class of flavonoids present in methanol leaf extract of $U$. gambir contained more catechin compounds 8,635\% CAE than stem parts 5,120\% CAE [32]. U. gambir's leaf extracts grown in Indonesia extracted by steaming (10 $\mathrm{min}$ ) had the more percentage yields and catechin contents than without pre-treatment processes [14]. Our resulting data were almost the same as previous researches.
Total phenolic and proanthocyanidin contents assay in the present study revealed that S. polyanthum's stem extract had the highest total phenolic and proanthocyanidin contents among S. polyanthum extracts which were $23,846 \pm 0,613 \%$ GAE and 23,336 $\pm 1,192$ followed by root parts 21,336 $\pm 0,810 \%$ GAE and $14,156 \pm 1,284$, the last was leaves extract 15,763 $\pm 0,588 \%$ GAE and 6,648 \pm 0,715, respectively. Nevertheless, flavonoid content was not followed phenol and proanthocyanidins's pattern. This study showed that total flavonoid content in the S. polyanthum extract was ranked as follows leaves $(38,633 \pm 4,926 \%$ RAE $)>$ stems $(18,000 \pm 0,495 \%$ $\mathrm{RAE})>$ roots $(12,088 \pm 1,697 \% \mathrm{RAE})$.

According to Wong et al., water extract of $S$. polyanthum's leaf collected in Singapore contained $1,1 \%$ GAE dry weight total phenolic content [33]. In contrast, methanol extracts of $S$. polyanthum's leaf in the present study contained higher total phenolic content. The difference could be attributed to the high levels of total phenolic content in the S. polyanthum's leaf grown in Padang, West Sumatra, or due to the different method of extraction employed.

The calculation of total phenolic, flavonoid, and proanthocyanidin content of $U$. gambir and S. polyanthum extracts was presented in Table 2.

Table 2: Total phenolic, flavonoid, and proanthocyanidin contents

\begin{tabular}{llll}
\hline Sample & $\begin{array}{l}\text { Total phenolic } \\
\text { contents } \\
\left(\% \mathrm{GAE}^{2}\right)\end{array}$ & $\begin{array}{l}\text { Flavonoid } \\
\text { content } \\
\left(\% \mathrm{RAE}^{3}\right)\end{array}$ & $\begin{array}{l}\text { Proanthocyanidin } \\
\text { content }\left(\% \mathrm{CAE}^{4}\right)\end{array}$ \\
\hline U. gambir's naturally dried leaf & $29,659 \pm 2,521$ & $32,472 \pm 1,095$ & $14,293 \pm 0,671$ \\
U. gambir's oven dried leaves & $17,580 \pm 0,529$ & $27,352 \pm 1,902$ & $8,422 \pm 0,466$ \\
U. gambir's steam dried leaf & $42,536 \pm 1,047$ & $29,396 \pm 1,742$ & $37,927 \pm 1,267$ \\
U. gambir's stems & $27,735 \pm 1,455$ & $67,613 \pm 0,826$ & $16,699 \pm 0,544$ \\
U. gambir's roots & $18,088 \pm 0,619$ & $32,456 \pm 1,286$ & $12,226 \pm 0,371$ \\
S. polyanthum's leaf & $15,763 \pm 0,588$ & $38,633 \pm 4,926$ & $6,648 \pm 0,715$ \\
S. polyanthum's stem & $23,846 \pm 0,613$ & $18,000 \pm 0,495$ & $23,336 \pm 1,192$ \\
S. polyanthum's root & $21,336 \pm 0,810$ & $12,088 \pm 1,697$ & $14,156 \pm 1,284$ \\
Proanthocyanidin fraction & not determined & not determined & $79,946 \pm 1,100$ \\
\hline Means \pm SEM & & &
\end{tabular}

\section{Inhibition of alpha-glucosidase}

alpha-glucosidase is an enzyme produced by the villi lining the small intestine of mammals and is responsible for the hydrolysis of disaccharides to monosaccharide that can be absorbed and consequently elevate blood glucose levels. Inhibition of intestinal alpha-glucosidase has been used successfully as a therapeutic target for modulation of post-prandial hyperglycemia, which is the earliest metabolic abnormality to occur in type 2 DM [34], [35]. The alpha-glucosidase inhibiting activity of the eight plant extracts was tested following the method described by Mohamed et al [21]. This microplate assay offers great convenience, speed, and reproducibility. The alpha-glucosidase inhibitory activity was determined by measuring a yellow color due to the release of p-nitrophenol from $\rho$-nitrophenyl- $\alpha$-D-glucopyranoside. ${ }^{2}$

$2 \%$ GAE : percent of gallic acid equivalent

$3 \%$ RAE : percent of rutin equivalent

$4 \quad \%$ CAE : percent of $(+)$-catechin equivalent 
The alpha-glucosidase $50 \%$ inhibitory concentrations $\left(\mathrm{IC}_{50}\right)$ for the methanol extract of different parts and plants, as well as the positive control, acarbose, was depicted in Table 3. It was evident from the results that $U$. gambir's oven-dried leaf extracts inhibited $\alpha$ lphaglucosidase the most with a $\mathrm{IC}_{50}$ value of $36,865 \pm$ $1,187 \mu \mathrm{g} / \mathrm{ml} . \quad \mathrm{IC}_{50}$ value of $111,286 \pm 2,386 \mu \mathrm{g} / \mathrm{ml}$ was obtained for the positive control, acarbose. Interestingly, all extracts tested were more potent inhibitors of $\alpha$ lphaglucosidase than acarbose.

Table 3: Inhibitory effect $\left(\mathrm{IC}_{50}\right)$ of samples and positive control acarbose for alpha-glucosidase

\begin{tabular}{ll}
\hline Sample & $\mathrm{IC}_{50}(\mu \mathrm{g} / \mathrm{ml})^{\mathrm{a}}$ \\
\hline$U$. gambir & \\
Leaf & \\
$\quad$ Naturally dried & $40,194 \pm 2,437$ \\
Oven dried & $36,865 \pm 1,187$ \\
Ethyl acetate fraction & $29,474 \pm 0,485$ \\
Butanol fraction & $20,471 \pm 0,705$ \\
Steam dried & $40,278 \pm 1,500$ \\
Stem & $40,305 \pm 1,398$ \\
$\quad$ Hexane fraction & $201,688 \pm 2,194$ \\
Ethyl acetate fraction & $37,479 \pm 0,467$ \\
Butanol fraction & $23,331 \pm 1,637$ \\
Root & $44,683 \pm 2,637$ \\
S. polyanthum & \\
Leaf & $53,431 \pm 1,498$ \\
Ethyl acetate fraction & $35,861 \pm 2,384$ \\
Butanol fraction & $28,469 \pm 1,929$ \\
Stem & $56,593 \pm 2,475$ \\
Hexane fraction & $233,861 \pm 2,888$ \\
Ethyl acetate fraction & $29,124 \pm 0,450$ \\
Butanol fraction & $30,465 \pm 0,502$ \\
Root & $58,222 \pm 3,751$ \\
$\quad(+)$-Catechin & $30,855 \pm 0,791$ \\
Proanthocyanidin fraction & $28,993 \pm 1,377$ \\
Acarbose & $111,286 \pm 2,386$ \\
\hline average of three determinations, mean $\pm S E M(n=3)$ &
\end{tabular}

Previous reports have shown that bioactive compounds such as flavonoids and phenolics, from a wide range of food or medical plant sources, could be effective alpha-glucosidase inhibitors [36]. Our study demonstrated that the $\mathrm{IC}_{50}$ value of the alphaglucosidase activity of $U$. gambir extracts was not correlate with the level of phenolic, flavonoid, and proanthocyanidin contents. Therefore, it is rationally presumed that extracts may have other different active components.

Based on Table 3, U. gambir's oven-dried leaf extracts exhibited the highest $\alpha$ lpha-glucosidase inhibitory activity among the extracts, meanwhile its phenolic, flavonoid, and proanthocyanidin content were the lowest among other U. gambir extracts. Benalla et al. [9] suggested that many kinds of natural products show strong activity against $\alpha$ lpha-glucosidase such as alkaloids, saponin, steroid, polyphenol, terpenoid, acids (chlorogenic acid, betulinic acid, syringic acid, vanillic acid, bartogenic acid, oleanolic acid, dehydrotrametenolic acid, corosolic acid, ellagic acid, ursolic acid, and gallic acid), phytosterol, myoinositol, flavonoids, flavonolignans, anthraquinones, anthrones, xanthones, feruloylglucosides, flavanone glucosides, acetophenone glucosides, glucopyranoside derivatives, genine derivatives, flavonol, anthocyanin, and others [37], [38], [39], [40], [41], [42].

It has been mentioned that $U$. gambir's ovendried leaf extracts react positively in all phytochemical screening tests. The low relationship confirms that phenolic, flavonoid, and proanthocyanidin compounds were not the only contributor to the alpha-glucosidase activities of the extracts. The type and quantity of phenolic compound and the presence of nonphenolic antioxidant contents may contribute to the antioxidant activity of the extracts. Moreover, it could be due to synergistic interaction of phenolics, flavonoid, proanthocyanidin, and also interaction with nonphenolic compounds which may be an important factor in contributing to the total alpha-glucosidase activity [43].

We demonstrated that all of the U. gambir extracts had higher activity than acarbose. Our findings were in line with previous data performed by Kim, who conducted alpha-glucosidase inhibitory activity assay of eight compounds of aqueous methanolic extract of manufactured gambir product from $U$. gambir collected in Hunan province, China. Kim proved that all of the compounds as a result of isolation along with the Diaion HP-20 column chromatography fraction (30.3 $\pm 2.7 \mu \mathrm{g} / \mathrm{ml}$ ) showed a potent inhibitory activity $\alpha$ lphaglucosidase $\left(\mathrm{IC}_{50}\right.$ acarbose $312.6 \pm 3.8 \mu \mathrm{M}=201$, $42 \mu \mathrm{g} / \mathrm{ml})$ [44].

Our study suggested that the $\mathrm{IC}_{50}$ value of S. polyanthum extracts was not correlate with the level of phenolic, flavonoid, and proanthocyanidin contents. Our data supported the previously published reports. Twenty of the Syzygium sp. were tested for its antidiabetic property through alpha-glucosidase inhibitory assay. The results demonstrated that $\mathrm{IC}_{50}$ value of 20 Syzygium sp. ranged from 8.71 (S. cumini) $-72.63 \mu \mathrm{g} / \mathrm{ml}$ (S. samarangense), while quercetin as a standard was IC $\mathrm{IC}_{50} 22,39 \mu \mathrm{g} / \mathrm{ml}$ (45). IC $\mathrm{I}_{50}$ of $S$. polyanthum $(19,06 \mu \mathrm{g} / \mathrm{ml})$ collected in Bogor, Indonesia, showed strong activity against alpha-glucosidase enzyme better than acarbose $(36,98 \mu \mathrm{g} / \mathrm{ml})$ (8). Polyphenols were associated with the activity of $\alpha$ lpha-glucosidase inhibitors. The presence of other phytochemical compounds and synergistic action may play a role in $\alpha$-glucosidase activity of $U$. gambir extracts [46].

$U$. gambir's oven-dried leaf, $U$. gambir's stems, S. polyanthum's leaf, and S. polyanthum's stem were fractionated and tested for alpha-glucosidase activity. The results showed that the butanol fraction of $U$. gambir's oven-dried leaf had the most powerful alpha-glucosidase activity $\left(\mathrm{IC}_{50} 20,471 \mu \mathrm{g} / \mathrm{ml}\right)$. It is wellknown that the butanol fraction contains more polar compounds than the ethyl acetate fraction [9]. Hence, it can be concluded that the polar component plays a major role in the activity of alpha-glucosidase inhibition.

To find out the polar compound that plays a role in alpha-glucosidase activity, butanol fraction of $U$. gambir's oven-dried leaf was then prepared by Diaion HP-20 to give a proanthocyanidin fraction (purity of $>75 \%$ ). The alpha-glucosidase activity of the proanthocyanidin fraction showed an $\mathrm{IC}_{50}$ of $28,993 \mu \mathrm{g} / \mathrm{ml}$ and as a comparison, the compound (+)-catechin has an $I_{50}$ of $30.85 \mu \mathrm{g} / \mathrm{ml}$. The $I C_{50}$ 
value of the proanthocyanidin fraction is stronger compared to $(+)$-catechins because the general structure of the proanthocyanidin group compounds has more $\mathrm{OH}$-groups than (+)-catechins thus making it more polar. This research is in line with Kim who stated that $\mathrm{IC}_{50}$ value of procyanidin B3, a group of proanthocyanidin is $17.3 \mu \mathrm{M}$ and (+)-catechin was $53.8 \mu \mathrm{M}$, while acarbose was $312.6 \mu \mathrm{M}$. Kim showed that an $\mathrm{IC}_{50}$ value of proanthocyanidin has a strength almost $3 x$ than $(+)$-catechin [44]. This is different from our study because the components we tested were proanthocyanidin fraction, so there may a role for other components as inhibitors of alpha-glucosidase enzyme.

\section{Conclusion}

In the present study, different parts of $U$. gambir extracts, S. polyanthum extracts, and U. gambir's derived fraction and compound possessed inhibitory activity against alpha-glucosidase in vitro. Moreover, phenolics, flavonoids, and proanthocyanidins were found to be partly responsible for bioactivities of these extracts. These results indicated that both of $U$. gambir and S. polyanthum extracts could be utilized as a renewable bioresource to develop potential antidiabetic agents. Furthermore, methanol extraction could be an effective step for obtaining natural antioxidants from these samples, although further optimization of extraction is required.

\section{References}

1. Tsimogiannis D, Oreopoulou V. Classification of phenolic compounds in plants. In: Polyphenols in Plants. Cambridge: Academic Press; 2019. p. 263-84

2. Zhang YJ, Gan RY, Li S, Zhou Y, Li AN, Xu DP, et al. Antioxidant phytochemicals for the prevention and treatment of chronic diseases. Molecules. 2015;20(12):2113856. https://doi.org/10.3390/molecules201219753 PMid:26633317

3. Andasuryani A, Purwanto YA, Budiastra IW, Syamsu K. Determination of catechin content in gambir powder from dried gambir leaves quickly using FT NIR PLS model. Int J Adv Sci Eng Inf Technol. 2014;4(5):303-7. https://doi.org/10.18517/ ijaseit.4.5.423

4. Pambayun R, Gardjito M, Sudarmadji S, Rahayu KK. Kandungan fenolik ekstrak daun gambir (Uncaria gambir Roxb) dan aktivitas antibakterinya. Agritech. 2007;27(2):89-94.

5. GuariguataL, WhitingDR, HambletonI, BeagleyJ,LinnenkampU, Shaw JE. Global estimates of diabetes prevalence for 2013 and projections for 2035. Diabetes Res Clin Pract. 2014;103(2):13749. https://doi.org/10.1016/j.diabres.2013.11.002 PMid:24630390

6. Vinayagam R, Jayachandran M, Xu B. Antidiabetic effects of simple phenolic acids: A comprehensive review. Phytother
Res. 2016;30(2):184-99. https://doi.org/10.1002/ptr.5528 PMid:26634804

7. Ahmad R, Hashim HM, Noor ZM, Ismail NH, Salim F, Lajis NH, et al. Antioxidant and antidiabetic potential of Malaysian Uncaria. Res J Med Plant. 2011;5(5):587-95. https://doi.org/10.3923/ rjmp.2011.587.595

8. Elya B, Handayani R, Sauriasari R, Hasyyati US, Permana IT, Permatasari YI. Antidiabetic activity and phytochemical screening of extracts from Indonesian plants by inhibition of alpha amylase, alpha glucosidase and dipeptidyl peptidase IV. Pak J Biol Sci. 2015;18(6):279-84. https://doi.org/10.3923/ pjbs.2015.279.284

9. Benalla W, Bellahcen S, Bnouham M. Antidiabetic medicinal plants as a source of alpha glucosidase inhibitors. Curr Diabetes Rev. 2010;6(4):24754. https://doi.org/10.2174/157339910791658826 PMid:20522017

10. Hidayati MD, Ersam T, Shimizu K, Fatmawati S. Antioxidant activity of Syzygium polyanthum extracts. Indones J Chem. 2017;17(1):49-53. https://doi.org/10.22146/ijc.23545

11. Kurzawa M, Filipiak-SzokA, Kłodzinska E, SzłykE. Determination of phytochemicals, antioxidant activity and total phenolic content in Andrographis paniculata using chromatographic methods. J Chromatogr B. 2015;995:101-6. https://doi.org/10.1016/j. jchromb.2015.05.021

12. Zebua EA, Silalahi J, Julianti E. Hypoglicemic activity of gambier (Uncaria gambir Robx.) drinks in alloxan-induced mice. In: IOP Conference Series: Earth and Environmental Science, 2017 Nov $7-8^{\text {th }}$, Medan, Indonesia. Bristol, England: IOP Publishing; 2018. https://doi.org/10.1088/1755-1315/122/1/012088

13. Roshanak S, Rahimmalek M, Goli SA. Evaluation of seven different drying treatments in respect to total flavonoid, phenolic, Vitamin C content, chlorophyll, antioxidant activity and color of green tea (Camellia sinensis or $C$. assamica) leaves. J Food Sci Technol. 2016;53(1):721-9. PMid:26787992

14. Sudibyo A, Joseph J. The effect of variety and methods of extraction on the yield and content of catechin of gambir (Uncaria gambir Roxb). Warta Industri Hasil Pertanian. 1988;5(1):28-31.

15. Chua LY, Chua BL, Figiel A, Chong CH, Wojdyło A, Szumny A, et al. Antioxidant activity, and volatile and phytosterol contents of Strobilanthes crispus dehydrated using conventional and vacuum microwave drying methods. Molecules. 2019;24(7):1397. https://doi.org/10.3390/molecules24071397 PMid:30970652

16. Harborne JB. Phytochemical Methods Simplified Method Wizard Analyzing Plant, Translation of Phytochemical Methods. Bandung: ITB; 1987.

17. Slinkard K, Singleton VL. Total phenol analysis: Automation and comparison with manual methods. Am J Enol Vitic. 1977;28:49-55

18. Woisky R, Salatino A. Analysis of propils: Some parameters and procedure for chemical quality control. J Agric Res. 1998;37:99105. https://doi.org/10.1080/00218839.1998.11100961

19. Sun B, Ricardo-da-Silva JM, Spranger I. Critical factors of vanillin assay for catechins and proanthocyanidins. J Agric Food Chem. 1998;46:4267-74. https://doi.org/10.1021/jf980366j

20. Hagerman AE, Butler LG. Assay of condensed tannins or flavonoid oligomers and related flavonoids in plants. In: Methods in Enzymology. Cambridge, Massachusetts: Academic Press; 1994. p. 429-37. https://doi.org/10.1016/0076-6879(94)34113-3

21. Mohamed EA, Siddiqui MJ, Ang LF, Sadikun A, Chan SH, Tan SC, et al. Potent alpha-glucosidase and $\alpha$-amylase inhibitory activities of standardized $50 \%$ ethanolic extracts and sinensetin from Orthosiphon stamineus Benth as anti-diabetic mechanism. BMC Complement Altern Med. 2012;12(1):176. https://doi.org/10.1186/1472-6882-12-176 


\section{PMid:23039079}

22. Rudra SG, Shivhare US, Basu S, Sarkar BC. Thermal inactivation kinetics of peroxidase in coriander leaves. Food Bioprocess Tech. 2008;1:187-95. https://doi.org/10.1007/ s11947-007-0013-2

23. Thorpe JF, Whiteley MA. Thorpe's Dictionary of Applied Chemistry. $4^{\text {th }}$ ed. London: Longman, Green and Co.; 1921.

24. Amir M, Mujeeb M, Khan A, Ashraf K, Sharma D, Aqil M. Phytochemical analysis and in vitro antioxidant activity of Uncaria gambir. Int J Green Pharm. 2012;6(1):67-72. https:// doi.org/10.4103/0973-8258.97136

25. Kusuma IW, Kuspradini H, Arung ET, Aryani F, Min YH, Kim JS, et al. Biological activity and phytochemical analysis of three Indonesian medicinal plants, Murraya koenigii, Syzygium polyanthum and Zingiber purpurea. J Acupunct Meridian Stud. 2011;4(1):75-9. https://doi.org/10.1016/s2005-2901(11)60010-1 PMid:21440883

26. Widyawati T, Yusoff N, Asmawi M, Ahmad M. Antihyperglycemic effect of methanol extract of Syzygium polyanthum (Wight.) leaf in streptozotocin-induced diabetic rats. Nutrients. 2015;7(9):7764-80. https://doi.org/10.3390/nu7095365 PMid:26389944

27. Manach C, Scalbert A, Morand C, Remesy C, Jimenez L. Polyphenols: Food sources and bioavailability. Am J Clin Nutr. 2004;79:727-47. https://doi.org/10.1093/ajcn/79.5.727 PMid:15113710

28. Gliszczynska-Swiglo A, Ciska E, Pawlak-Lemanska K, Chmielewski J,Borkowski T, TyrakowskaB. Changes in the content of health promoting compounds and antioxidant activity of broccoli after domestic processing. FoodAddit Contam. 2006;23(11):1088$98 . \quad$ https://doi.org/10.1080/02652030600887594 PMid:17071511

29. Chenani SN, Hossein GS, Keramat J, Mehdipour L, Haghighi M. Effect of preparation, freezing and thawing methods on total phenolic and Vitamin C content, antioxidant activity, texture and minerals of pepper (Capsicum annuum). Iran J Food Sci Technol. 2017;14(63):51-62.

30. Rahmawati N, Fernando A. Kandungan fenolik dan aktivitas antioksidan ekstrak daun gambir kering (Uncaria gambir (Hunter) Roxb). Indones Chem Acta. 2013;4(1):1-6.

31. Jaya, IG, Leliqia NP, Widjaja IN. Uji aktivitas penangkapan radikal dpph ekstrak produk teh hitam (Camellia sinensis (L.) OK) dan gambir (Uncaria gambir (Hunter) Roxb) serta profil KLT-densitometernya. J Farm Udayana. 2012;1(1):86-101.

32. Nurliayana I, Nurul ZM, Rohaya A. Quantification of catechin in leaves and stems of Malaysian Uncaria gambir (Hunter) Roxb. By HPLC-dad. MJAS. 2016;20(3):567-72. https://doi. org/10.17576/mjas-2016-2003-15

33. Wong SP, Leong LP, Koh JH. Antioxidant activities of aqueous extracts of selected plants. Food Chem. 2006;99(4):775-83. https://doi.org/10.1016/j.foodchem.2005.07.058

34. Hiroyuki F, Tomohide Y, Kazunori O. Efficacy and safety of touchi extract, an alpha-glucosidase inhibitor derived from fermented soybeans, in non-insulindependent diabetic mellitus.
J Nutr Biochem. 2001;12:351-6. https://doi.org/10.1016/ s0955-2863(01)00149-8

35. Krentz AJ, Bailey CJ. Oral antidiabetic agents: Current role in Type 2 diabetes mellitus. Drugs. 2005;65(3):385411. https://doi.org/10.2165/00003495-200565030-00005 PMid: 15669880

36. ShibanoM,KakutaniK, TaniguchiM, YasudaM,BabaK.Antioxidant constituents in the dayflower (Commelina communis L.) and their alpha-glucosidase inhibitory activity. J Nat Med. 2008;62(2):349-53. https://doi.org/10.1007/s11418-008-0244-1 PMid: 18409066

37. Dineshkumar B, Mitra A, Mahadevappa M. Antidiabetic and hypolipidemic effects of mahanimbine (carbazole alkaloid) from Murraya koenigii (Rutaceae) leaves. Int J Phytomed. 2010;2(1):22-30.

38. Choudhary MI, Adhikari A, Rasheed S, Marasini BP, Hussain N et al. Cyclopeptide alkaloids of Ziziphus oxyphylla Edgw as novel inhibitors of $\alpha$ lpha-glucosidase enzyme and protein glycation. Phytochem Lett. 2011;4(4):404-6. https://doi.org/10.1016/j. phytol.2011.08.006

39. Zhang SJ, Qu WJ, Zhong SY. Inhibitory effects of saponins from Tribulus terrestris on alpha-glucosidase in small intestines of rats. Zhongguo Zhong Yao Za Zhi. 2006;31(11):910-3. PMid:17048632

40. Choudhary MI, Shah SA, Khan SN, Khan MT. Alphaglucosidase and tyrosinase inhibitors from fungal hydroxylation of tibolone and hydroxytibolones. Steroids. 2010;75(12):95666. https://doi.org/10.1016/j.steroids.2010.05.017 PMid:20685216

41. Kumar D, Ghosh R, Pal BC. alpha-glucosidase inhibitory terpenoids from Potentilla fulgens and their quantitative estimation by validated HPLC method. J Funct Foods. 2013;5(3):1135-41. https://doi.org/10.1016/j.jff.2013.03.010

42. YingYM,ZhangLY,ZhangX,BaiHB,LiangDE,MaLF,etal.Terpenoids with alpha-glucosidase inhibitory activity from the submerged culture of Inonotus obliquus. Phytochemistry. 2014;108:1716. https://doi.org/10.1016/j.phytochem.2014.09.022 PMid:25446238

43. Kwon YI, Apostolidis E, Shetty K. Inhibitory potential of wine and tea against $\alpha$-amylase and alpha-glucosidase for management of hyperglycemia linked to Type 2 diabetes. J Food Biochem. 2008;32(1):15-31. https://doi. org/10.1111/j.1745-4514.2007.00165.x

44. Kim TH. A novel alpha-glucosidase inhibitory constituent from Uncaria gambir. J Nat Med. 2016;70(4):8115. https://doi.org/10.1007/s11418-016-1014-0 PMid:27262298

45. Saraswaty V. Alpha glucosidase inhibitory activity from Syzigium sp. J Teknol Indones. 2012;33:33-7.

46. XiaoJ,KaiG, YamamotoK, ChenX.Advanceindietarypolyphenols as alpha-glucosidases inhibitors: A review on structure-activity relationship aspect. Crit Rev Food Sci Nutr. 2013;53(8):81836. https://doi.org/10.1080/10408398.2011.561379 PMid:23768145 